\title{
"To remain working for the People" Ojibwe Women in an Indigenous Teacher Education Program
}

\section{"Continuar trabajando para el Pueblo" Mujeres Ojibwe en un Program de Educación de Maestros Indígenas}

\author{
"Rester à travailler pour les Gens" \\ Les Femmes Ojibwe dans un Programme de \\ Formation pour Enseignants Autochtones
}

\section{Kate Freeman \\ Queen's University}

\section{ABSTRACT}

This paper explores the role of relationships for eight Indigenous (Ojibwe) women enrolled in a Canadian teacher education program, specifically, the ways in which relationships pertained to Indigenous culture-creation and continuity through education. Findings from this small study suggest that there is some consistency in the relational orientations and in the roles of Ojibwe women past and present. The paper outlines ways in which study participants are demonstrating cultural continuity in fulfilling roles as learners and as teachers of Indigenous students. It concludes with questions and implications for the design and practice of Indigenous education.

Key words: Ojibwe women teachers, Indigenous teacher education, cultural continuity, Indigenous mentors, Canadian Aboriginal teacher education, Ojibwe relational orientations.

\section{RESUMEN}

Este trabajo examina el papel de las relaciones de ocho mujeres Indígenas (Ojibwe) matriculadas en un Programa de formación del profesorado canadiense. Concretamente, se analiza la manera mediante la cual el mundo relacional contribuye a la creación de cultura indígena y su continuidad a través de la educación. Los resultados de este pequeño estudio sugieren que hay cierta consistencia en la orientación relacional y en los roles de las mujeres Ojibwe a través del 
tiempo. El documento esboza el modo mediante el cual las estudiantes participantes muestran la continuidad cultural en el cumplimiento de sus funciones como aprendices y como profesoras de estudiantes indígenas. El artículo concluye con algunas cuestiones e implicaciones para el diseño y la práctica de la educación indígena.

Descriptores: Profesoras Ojibwe, Indígenas; Continuidad cultural, Consejeros indígenas, Aborígenes canadienses, Formación del profesorado, orientación relacional Ojibwe.

\section{RÉSUMÉ}

Ce papier explore le rôle des relations chez huit femmes autochtones (Ojibwe) inscrites à un programme de formation pour enseignants autochtones canadiens; spécifiquement, les manières dont les relations sont liées par l'éducation à la création et à la continuité de la culture indigène. Les conclusions de cette courte étude suggèrent qu'il existe une consistance dans les orientations relationnelles et dans les rôles des femmes Ojibwe du passé et du présent. Le papier trace dans les grandes lignes les manières dont les participantes à la recherche démontrent la continuité culturelle dans l'accomplissement des rôles comme apprenties et comme enseignantes aux étudiants autochtones. Il conclut par des questions et des implications pour le plan et la pratique de l'éducation autochtone.

Mots-clés : enseignantes Ojibwe, la formation des enseignantes indigènes, la continuité culturelle, les mentors indigènes, la formation des enseignants aborigènes canadiens, les orientations relationnelles Ojibwe.

\section{Introduction}

$\mathrm{T}$ HIS PAPER EXPLORES the role of relationships for eight Indigenous women enrolled in a Canadian teacher education program, specifically, the ways in which relationships pertained to Indigenous 'culture-creation' and continuity through education. Along with findings from literature, the paper presents excerpts from a twoyear study conducted in partial fulfillment of a doctoral degree. The study ${ }^{1}$ yielded a great deal of information pertaining to Indigenous teacher education. (Interviews alone yielded over four hundred single-spaced transcribed pages.) Findings included information on program features identified as fostering Indigenous learners' success in post-secondary education; participants' perspectives on Indigenous adult development and change; and implications for further research. This paper focuses on some of the findings specifically pertaining to relationships, education, and cultural growth/continuity, a pervasive theme throughout the study.

\section{Background Information}

Participants in this study were "Anishenabe kwe" (Ojibwe women). Anishenabe First Nations are also known as "Ojibwe, " Ojibway," "Ojibwa," or, in the United States, "Chippewa." Data was gathered over a two-year period, through individual face-toface and telephone interviews with these eight women participants, from a demographic data questionnaire, a personal journal, through personal experience working in the field of Indigenous education, and from a review of current literature. This inquiry employed a qualitative approach, which was useful in providing access to the depth, breadth, and texture of the individual lives of the participants.

Study participants were highly motivated and successful students enrolled in an 
Indigenous teacher education program, and ranged in age from twenty-nine to fiftyone. Six of these women (Doris, Edna, Flora, Joan, Clara and Susan - pseudonyms used) were concurrently working in an educational setting while attending the teacher education program. All held band membership ("status") cards and were affiliated with a First Nations community, though not all were from the same reserve. One participant (Tania - pseudonym used) spoke English only, while the other seven (Doris, Edna, Flora, Joan, Clara, Susan and Celia — pseudonyms used) were fluent/ functional Ojibwe speakers.

Data was also gathered from literature in the fields of Indigenous Studies and Indigenous Education. It is important to note that the accounts and interpretations of Indigenous history and 'meaning-making' vary dramatically depending upon the source. Literature pertaining to Indigenous people may be clustered into three groups: 1) literature written by non-Indigenous people about Indigenous people from second-hand experience; 2) literature written by non-Indigenous people about Indigenous people from first-hand experience; and 3) literature written by Indigenous people about Indigenous people. My own writing falls within the second category, as a non-Indigenous person who has worked in the field of Indigenous post-secondary education for over twenty-five years.

Written accounts of Indigenous experience authored by non-Indigenous people far outnumber those accounts by Indigenous people themselves. ${ }^{2}$ Numerous Indigenous authors $^{3}$ stress the central importance of Indigenous (also called Aboriginal) 'voice,' and of Indigenous people themselves becoming published authorities on their lives and experience. In recognition of this fact, I have relied on writing and research by Indigenous authors, and particularly Ojibwe people themselves, where possible, in presenting information pertaining to Ojibwe culture and Indigenous education. Indigenous authors cited in this paper include Taiaiake Alfred, Kim Anderson, Jeanette Armstrong, Marie Battiste, Eddie Benton-Banai, Linda Miller Cleary, V.F. Cordova, Vine Deloria, Jim Dumont, Diane Hill, Cecil King, Verna Patronella Johnston, Thomas Peacock, N. Shoemaker, and Linda Tuhiwai Smith, among others.

Research with Indigenous participants who are successful in post-secondary education is useful to increase knowledge and advise practice in the field of Indigenous post-secondary education. Indigenous people in Canada are still much less likely to have a university degree than non-Indigenous people. As the most recent Statistics Canada Census (2006) shows, post-secondary degree attainment continues to be an area of inequity for First Nation people. ${ }^{4}$ In the previous census (2001), an estimated 6 percent of the Indigenous population had a university degree, as compared with 20 percent of the non-Indigenous population. By 2006, although the number of Indigenous post-secondary graduates had increased, the gap had actually widened, with 8 percent of the Indigenous population holding a university degree, as compared with 23 percent of the non-Indigenous population. ${ }^{5}$ The situation for Indigenous people at the secondary level is even worse. In 2006, 50 percent of First Nation people aged twenty-five to sixty-four living on reserve had not completed high school, as compared with 15 percent of non-Indigenous people. ${ }^{6}$ The need to address such educational issues is particularly pressing in the author's home province 
of Ontario, where the highest population of Indigenous (i.e. Aboriginal, Metis and Inuit as shown on record) people in Canada resides (about 242,500, of the almost $1,173,000$ on record as living in Canada). ${ }^{7}$

As a final bit of background information to this paper, it is useful to note that, like other authors, ${ }^{8}$ I bring to my work a presupposition that knowledge is contextual in nature. Thus culture, or "what we do every day" ${ }^{9}$ has an impact on knowledge, and knowledge on culture. From this perspective, teaching and teacher education may be viewed as a powerful tool to de/reconstruct culture. It is with this perspective in mind that the activities of these Indigenous women as culture-creators-through-education become particularly interesting.

\section{Relationships, Teaching and Cultural Continuity: Findings}

While the study yielded many interesting findings, the most striking thing about the recorded interviews was how much all of the participants talked about themselves and their education-related experience in relation to others. The eight Indigenous women I interviewed were closely involved with and highly valued their family and community life. Relationships factored in their reasons for applying to a program of teacher education, in their learning and success while in the program, and in their intentions upon graduation. The theme of relationships emerged more frequently than any other, with all participants making comments in this area and with the frequency of comments exceeding those under any other theme. This theme was found in participants' comments on community responsibility and connection; on having mentors and being mentors; on culturally relevant classroom curriculum; and on investing efforts for the benefit of First Nation students and communities. Such findings are elaborated upon here.

\section{Community Responsibility and Connection}

We have to start healing our communities... I think that if we remember where we come from and if we can build upon that and start building, then the healing is going to happen.

- Celia

Mentioned by all participants and expressed more frequently than any other single concern was a sense of community responsibility and connection. A sense of community responsibility took the form of concern for the children and for present and future generations of Ojibwe people. The well-being of their communities and of the children in their communities was highly valued and desired. Participants spoke of various ways in which they could make positive contributions. Joan intended to use education as a tool to strengthen and nurture Indigenous children, saying

... I also have this great desire to, as it were, leave something with the young people and to be a part of their learning experience, to help them in their 
learning environment. And because I work with the young people and I know them really well here [on her reserve] I thought that, well, if I get my teaching certification, then I would be able to help them even more than I am now.... I thought if I could get into a teaching position - had my teaching certificate-I would want to be able to do some of those things to help the Native children ... because I see more Native children - some of them are losing ... we're losing them, you know, because they are not getting what they should be getting in terms of their teaching and so forth. So I thought if I could be part of that group or have an influence on them, anything that makes the education of the young people better education for them, that certain something I would be working for.... And I thought that if, uh, if the Native teacher programs could do this; more of positive things of teaching in their graduates then we would be at least, uh, reaching some of our students and making sure that they receive the type of education that should be given to them so that they are aspiring to something, you know, specifically. The whole thing is that kids are good at one thing or another, and to work on that and make them feel that they're part of society, that they are giving to society.

Participants were aware that children in their communities were at risk, and viewed education as a way to reinstate a positive sense of what it means to be Indigenous. As Celia said,

...like self-esteem in kids.... They are always so down here, you know? We've got to start bringing them back up here, so they become strong again ... because they're the future leaders and what's it going to be like seven generations from now, you know, if we don't start making them strong? And we have to start healing our communities. It's not going to happen over night but ... I think that if we remember where we come from and if we can build upon that and start building, then the healing is going to happen. More and more people become strong again, strong communities that are proud of who they are and know what they want and where they're going.... The ultimate for me is to see no alcoholism or drug abuse or sexual abuse or any kind of abuse ...- - you know, that would be an ultimate thing to see. But I think it's going to take a long time. But if we, we can be proud of those things that we already know and who we are, that is where the strength is going to come from....

Six of the eight participants indicated that they were motivated to become teachers by a love of children, as reflected in Susan's comment when asked what appealed to her about being a teacher:

I think it's the way, um, when you see kids and the kind of respect that they have for somebody who is teaching them, and what the teacher can do for that student as far as just opening their minds up to everything; to everything around them and to everything that's out there. I could see the kids. It's in their 
faces. That's the first thing I thought of when I thought of becoming a teacher, is seeing all these eager little faces. I thought, "If I could do that, to kids, then I would like to."

\section{Having Mentors, Being Mentors}

To know you have your role models, just like we are for the kids in our own communities...

\section{-Celia}

For these participants, six of whom had benefited from a mentoring relationship which encouraged them in their own roles as students, there was a clear perception that Indigenous children need Indigenous teachers and role models. Participants' role models were Indigenous learners who had successfully completed post-secondary education programs themselves: family members, other Indigenous women, an Indigenous librarian, and Indigenous professors who had either encouraged them directly or by example. The challenges participants faced in becoming students and teachers were mitigated by those Indigenous individuals who had gone before them and showed them the way. Clara described how, after she became an adult, one significant person changed her long-standing negative attitude to school. She said

...we used to live with this older couple, and she was a teacher, a very dedicated teacher and ... she was always learning. And she was always taking courses. And I think it was from listening to her saying, oh, she said she will always take courses, and how she seemed to look at it. Like it was so exciting. And I think maybe that's kind of where I changed my attitude.

Flora cited the presence of an Indigenous educator as the main factor prompting her to stay in the teacher education program at the outset. "My first experience, a memorable experience, was [mentions Indigenous professor's name]. When he saw that I was going to [quit the program and] leave at twelve o'clock he came in and he just started talking about all this Native stuff, and I was fascinated! And ... [I thought] "Oh! I want to be a Native professor..." Similarly, Celia recalled the influence of an Indigenous professor and role model who taught her about significant Indigenous individuals, saying "...[name omitted] turned it around and made it positive for us, you know, to say that these ... heroes are things that we need to teach our children, because it's so important to be proud of who you are and where you come from...."

Just as participants had benefited from mentoring relationships, they wished to be role models themselves, as a way of encouraging the children in their own community schools. As Flora said

I feel more strongly now than ever that we need more Native people in the school.... I wish that there were more Native teachers.... And I just think it's really, really important that we have a lot more [Native] people in education.... It's very important that those children see good role models in the school. 
Good ones.... I want to be encouraging. I want to be a role model in the school for the kids. Most of the kids live on the Reserve and they don't see any of the outside life and, um, they don't see any Native people working in the school. They don't see Native people working anywhere else but on the Reserve, and by being a teacher in the school I'm showing them. And they also know that I'm going to school, so they know that education is a life-long experience, and I want to show them that; and show them that learning can be fun.... I'm helping to build up their self-esteem and giving them interest in education.

Aware of both having been mentored and of having a mentoring role, Celia talked about 'passing it on' in saying

....as a Native role model, I would ... say that she was influential.... And that's how I see that the kids today need that too, in their schools, their Native educators to be there for them.... because most of my teachers were non-Native teachers from other - I don't think I've ever had a Native teacher-besides my mother [laughs], you know. Like in the school setting, never, never. It was always non-Native teachers or from other nationalities....

I think it's ... Native education for Native people by Native people. I guess that's probably a cliché that we heard a lot of times, but I think there's some truth to that, you know? To know that you have your role models, just like we are for the kids in our own communities; that people are going to be more accepting of their protegés or their own role models, saying "This is what we offer and this is what we'd like to have you teach, or, this is what we'd like to have you learn.".... 'cause when you're working in the school you see them and they're so receptive to their own, to their own people.

As Edna described it

...they require someone from ... their own culture to start relating to them in other ways.... These [Indigenous] students, they have English as their second language. And there were ways that there were barriers, like the teachers were - their teaching methods were great.... I learned a lot from the teachers that I worked with — but yet there was still a barrier.... I'd say I wanted, I felt that I, myself, would at least be able to help at least some Native students as best as I could.

\section{Culturally Relevant Classroom Curriculum}

Even if the program didn't have a little bit of our culture and traditions ... I would have put those in myself... 
Participants conveyed an understanding that schooling was problematic for Indigenous students in terms of curriculum content and teaching methods which ignored Indigenous needs and interests. In all, six participants (Doris, Clara, Joan, Flora, Celia and Edna) envisioned ways in which they could improve the educational experience for their own Indigenous students by adding their own Indigenous culture, methods and language to classroom content. This was a role which could not be filled in the same way by a non-Indigenous teacher. As Celia said "...we have to be able to tell it from our own point of view."

Doris viewed herself as one who could increase Indigenous cultural content in school curriculum, saying

...I think even if [the program] didn't have a little bit of our culture and traditions, I probably would have put those in [my classroom] myself in being a teacher.... And I figure there's got to be a way that you can get parents involved right in the classroom.

When talking about her goals as an educator, Celia, said

I can bring [cultural content], and being of Native ancestry ... I would be able to bring that to them, through that channel of being a Native teacher. And that, to me is important ... to contribute what I know, my experiences, and relate my experiences because I think that's probably, as a person that's all you can do for someone else ... and to give them inspiration to go on. I think that's really needed, especially among the Native children, to know that there is something that they can shoot for, you know, that they have the ability to do that...

Edna saw one of her contributions to teaching as raising the awareness of other teachers in her First Nation school setting regarding Indigenous childrens' learning needs and different learning styles. She hoped to apply some of her learnings, because, as she said

...especially with Native populations, Native children, as experienced myself, are not getting the full benefit.... of the education system. And we're really not grasping the knowledge as well as we should have been.... And I found that as I did more research... there were different ways of learning for Native people. And that got me more interested in Native education itself. And I knew there was more that I could do, that there was more out there.

She and Clara hoped to develop curriculum to address Indigenous student needs, including the need for learning activities accommodating a variety of different learning styles.

Joan, along with other participants, was deeply concerned about Aboriginal language. When speaking of her future goals she said "...I would like to be able to focus 
on the teaching of my language and my culture to the young people." These women were aware of the intertwined relationships between language, culture and thought, and knew that language education must be a priority.

Some participants recognized school as an instrument of the dominant culture, successfully used to suppress Indigenous culture, with the resulting loss of Indigenous cultural knowledge and language. Celia referred to how the image of Indigenous culture as inferior has been internalized by some Indigenous people (in a 'Stockholm Syndrome'-like way, aligning with the oppressor). ${ }^{10}$ Education for Indigenous people by Indigenous people was seen as a way of redressing wrongs, and of reclaiming a positive perception of both Indigenous self and of education. Celia indicated the challenge of such a task when she said

I was thinking about the culture that's being taught in the school, how we've come five hundred years; it's taken us five hundred years as Native people to get where we are ... some people aren't just going to want to turn right around and be able to accept the culture back in the school.... it's going to have to take time, and unfortunately that time is also going to lose a lot of things. So, I think, you know, we have to really rely on our Elders to bring that [cultural content] to the school, or to the children in some way.... As far as teaching goes ... one important thing is to always remember where you come from and who you are.... I think you have to look at that too for the children ... and to appreciate who they are...

Such cultural content included education on moral values concerning right and proper relations with others. As Celia said,

... the first teaching I learned was that you accept another person no matter what race, creed or colour they are, and that you accept them for what they are.... And other things, like you don't treat people like that; you treat people like that and it's going to come back to you. You know, those teachings that the Elders have given us.... treating a person kindly, with kindness and with respect and with love; the seven gifts that your Creator has given you, ${ }^{11} \mathrm{I}$ think those are the really strong influences.

For some, a desire to offer such Indigenous cultural content on was extended to include the broader community in general. Tania said this about what she hoped her contribution would be:

...to motivate [students], to get them interested in something ... if I teach on my Reserve, to get them interested in who they are, and how important their life is, and that they matter. That we're not just doing this to hassle children for eight hours a day. Like they're going to get something out of it.... If I'm working in the city as a Native teacher ... then I hope I can transfer the richness of my heritage to other teachers and to the kids. Whether they are Native 
or non-Native. Everybody should know ... that there isn't just one view of the world, that the continent didn't start in 1492 and never existed prior. If I can share positive information about who I am and who Native peoples are, with other teachers or non-Native students, and give them a different light on that story, then that would be great. Or if I can do it on a Reserve in such a way, where the students just know that it's their heritage. I don't want to really teach it to them. I want them to live it, you know, as students. It'll just be part of our every day. Put it on the board in Ojibwe, you know, like it will just be part and maybe become natural to them...

\section{Investing their Efforts for the Benefit of First Nation Students and Communities}

...if there's something I could do for my community, then that's where I would like to be. I would like to remain working for the People.

- Susan

All participants mentioned ways in which they hoped to benefit their First Nation communities and students, and viewed education as a vehicle to further their efforts in this regard. When discussing their intentions upon graduation, seven of the eight participants expressed commitment to their community by indicating that they intended to stay and use their new expertise in their home communities. (Note: Since the time of the interviews the eighth participant, Tania, has returned to her home reserve to teach.)

While all participants expressed a desire to invest their efforts for the benefit of their people, significantly, none of the participants mentioned a purely individualistic motivation to become a teacher.

\section{Relationships, Teaching and Cultural Continuity: Discussion}

Relationships with family, community, and Indigenous students were foremost in participants' lives. These women shared the perception that their communities and children were at risk, and viewed education as a tool to assist in alleviating the social and cultural problems they faced. Through the avenue of education, participants sought ways in which they could exercise agency in identifying and creating learning conditions to foster Indigenous cultural sustenance and growth. They were motivated to do so by an abiding concern for their communities and children.

\section{Ojibwe Women as Teachers, Past and Present}

Though there have been inevitable changes since historical times, there is also some consistency in the roles of Ojibwe women past and present. Historically, education 
was a communal responsibility, as E. J. Danziger points out in referring to Ojibwe (Chippewa) practices:

To fit the child into the proper cultural pattern was the general goal of family educational practices.... Chippewa educational practices were aimed at teaching the child the religious, economic and political practices as well as the moral standards of the tribe. Lessons were learned from all members of the household - parents, grandparents, brothers, sisters - and from respected older members of the village. ${ }^{12}$

Yet while the extended family was fully involved in raising Ojibwe children, women played the most extensive role in this regard, due to the fact that in a hunting and gathering society, the division of labour was distinct, with the women maintaining the home and the men often away for extended periods of hunting.

Indigenous women had significant roles to play in their communities' cultural survival and continuity. As Indigenous author N. Shoemaker summarizes, "Native women maintained the cultural traditions of their people. They also, on other occasions, advocated change. They were, in short, crucial participants in the ongoing struggle for the survival of Indian cultures and communities." ${ }^{13}$ Indigenous women served as the first teachers and purveyors of culture, with cultural knowledge being passed from mother to child. Teaching ensured "the transmission of cultural D.N.A. from one generation to the next." 14

This historical responsibility to maintain the cultural traditions of their people is echoed today in the study participants' comments about offering culturally relevant curriculum, and building a positive sense of what it means to be Indigenous. In their sense of responsibility for their students and communities, participants were like other contemporary Indigenous women discussed by Indigenous author Kim Anderson. ${ }^{15}$ When she interviewed forty Indigenous women of various First Nations, she saw prevailing patterns in their roles as nurturers and community builders, and concluded that Indigenous women "not only birth the people, we have been given a lifetime responsibility to nurture the people." ${ }^{16}$ There was an awareness among my study participants that they could and should do something to address the barriers and the cultural gap between school and home. In expressing this awareness of difference and the desire to support their own ways, they were like other Indigenous people across the country. ${ }^{17}$ Consider, for example, Indigenous author and educator Jeannette Armstrong's reflections on her educational experience in British Columbia, Canada:

I enjoyed my school years, but I realized at that time that there was a big difference, a huge difference between the way my people taught and how the teacher was thinking. ${ }^{18}$

Participants were seeking to assume proactive, pragmatic roles to ensure that culture may be passed on through the education system. As such, they joined with a larger 
movement in Indigenous education which has long sought to reclaim control of education. As the landmark national study conducted by the Royal Commission on Aboriginal Peoples ${ }^{19}$ revealed

For more than 25 years, Aboriginal people have been articulating their goals for Aboriginal education. They want education to prepare them to participate fully in the economic life of their communities and in Canadian society. But this is only part of their vision. Presenters told us that education must develop children and youth as Aboriginal citizens, linguistically and culturally competent to assume the responsibilities of their nations.... Many Aboriginal leaders speak of resuming control of education, since First Nations and Inuit exercised complete control of education for countless generations. Rather than being a new responsibility, self-determination in education was practised by families and communities in earlier times. ${ }^{20}$

The education and educators of Indigenous children have changed markedly, yet the role of Indigenous woman as culture-sustainer-through-education continues today. Participants' comments showed that for them, formal education was positively valued, which is quite remarkable, considering that all participants had relatives and/ or acquaintances who were subjected to residential school, and considering that educational policies and practices have continued to subjugate and degrade Indigenous ways of being. However, regaining control of education is seen as a necessary step toward reclaiming Indigenous cultural and community knowledge damaged through a formal system of educational hegemony perpetuating epistemologies of the dominant society. Indigenous scholar Marie Battiste refers to such epistemic issues using the term "cognitive imperialism."

Cognitive imperialism is a form of cognitive manipulation used to disclaim other knowledge bases and values. Validated through one's knowledge base and empowered through public education, it has been the means by which whole groups of people have been denied existence and have had their wealth confiscated. Cognitive imperialism denies people their language and cultural integrity by maintaining the legitimacy of only one language, one culture and one frame of reference....

In the Canadian educational system today, Aboriginal people continue to be invisible. Occasional pictures in books are the only images of participation in the educational world.... The cultural imperialistic curriculum in these schools has degraded and demoralized cultural minority students, assigned them to transitional classes, failed them, and then accused them of lacking motivation, attention or spirit. ${ }^{21}$

Far from passive victims, however, study participants were not only culture-sustainers, but also culture-creators. They viewed education as an effective tool with which to exercise agency in this regard. Obtaining a teaching credential, they were quietly 
positioning themselves as insiders in a "culture of power" ${ }^{22}$ which dictates what may be taught. Yet, far from supporting the status quo, they planned to replace 'culturally imperialistic curriculum' with curriculum designed for their own Indigenous students; to teach Ojibwe language; and to encourage their students' talents and gifts. They were striving, through education, to fulfill "the right of females to be what we fundamentally are - insurers of the next generation." ${ }^{23}$ Participants understood that "the destiny of a people is intricately bound to the way its children are educated," 24 and that, through education, they could be agents of positive change for the future, fostering "strong communities that are proud of who they are" (Celia).

\section{Relationships Permeate Everything/Everything Permeates Relationships}

Some of the literature on the cultural characteristics of Ojibwe people specifically, and on Indigenous people in general, supports the idea that the strong emphasis participants placed on relationships is a cultural trait. Indigenous author Diane Hill reports a personal conversation with Indigenous educator, R. A. Antone, in which he said

In Aboriginal thought, a human being must learn how to function within a 'total environment' of ever expanding circles of relationships. Beginning with one's family, the human being's interactions will extend into his/her clan, community, and nation; will move outward to other nations and races of people; and extend further still to include the global environment and all the Universal elements within the Creation. A disruption in any one of these circles impacts on the whole. ${ }^{25}$

This emphasis on relationships and interconnections is echoed in Julie Cruikshank's comments about Aboriginal womens' stories. Cruikshank ${ }^{26}$ says, "The recurring theme is one of connection - to other people and to nature. Connections with people are explored through ties of kinship; connections with land emphasize sense of place. But kinship and landscape provide more than just a setting for an account, for they actually frame and shape the story."

An orientation which emphasizes interconnected relationships, and a concern for the well-being of the whole is not new. Numerous historical accounts suggest that for Anishenabe people traditionally, interconnections were of central importance. ${ }^{27}$ Teachings about right and proper relations extended beyond those referring to human relations to include the natural world as well. The Ojibwe self was not conceived of as autonomous and separate, but rather experienced as part of an interconnected web encompassing one's community and the rest of creation. As Jim Dumont, Ojibwe professor and scholar states

In formulating an understanding of themselves and their world, the ancestors of today's Aboriginal people reasoned that "all life exists as an interconnected 
reality" that was "designed by the Creator to function in a state of balance, harmony and interdependence." 28

The teachings of contemporary Ojibwe Elders have supported the idea that such relational orientations continue. I recall Fred Wheatley, a respected Ojibwe man and Ojibwe language professor at Trent University, telling me over twenty years ago that 'even the stones deserve respect as they too are part of living creation.' And I remember one of my mentors, Ojibwe academic Dr. Cecil King describing the Ojibwe (Anishenabe) view of humans' place in the order of things. He stated that in the Western view, human beings are placed at the top of a hierarchal pyramid of creation, superior and apart from the rest of creation. In the Ojibwe view, human beings are least necessary to and most dependent upon the rest of creation, which will exist without humankind, while humankind cannot do the same. This fundamental difference in the perceived place of humankind in the natural order means that according to Ojibwe beliefs, respect and honour must be shown to all, of which we are a part' [paraphrased from author's notes]. ${ }^{29}$

Relational orientation is embedded in the very language of many First Nations. Indigenous authors ${ }^{30}$ and others agree that language shapes the way people perceive and relate to the world around them. Language is foundational in forming our understandings. Consider the impact of language on relational orientations - for example, while the English language relies on nouns to name and relate to, Ojibwe, like other many Indigenous languages, is a descriptive language focusing on processes, cycles and the interrelationships of things, embodying a relate with orientation. Perhaps it is because language is the very embodiment of Indigenous ways of knowing that its presence or lack thereof in education is of particular concern to many Indigenous people. As Indigenous scholar Linda Tuhiwai Smith points out

Our communities... have become much more complicated. What we see now is an emergence of multiple voices and diverse voices. We, as indigenous peoples and communities, do not agree on everything. We don't understand words like 'self-determination' in the same way. We don't hold to the same ideologies.... We do not agree on everything [but] ... one of the things that binds us together is a love of our language. ${ }^{31}$

An emphasis on the importance of the whole is still exercised in a variety of ways among contemporary Ojibwe people. An example of this is the Ojibwe orientation toward money. Verna Patronella Johnston, an Elder and member of the Ojibwe First Nation at Cape Croker speaks of this orientation when she says

...the money value is different. Indians shared everything, so they didn't have to hoard, they didn't have to put money in the bank for their old age; they knew they would be looked after by the younger people. A lot of Indians still don't hoard money. Even some of those with steady jobs are broke at the end of the month because they share their money. ${ }^{32}$ 
Another example of a relational orientation which emphasizes equality and respect for the whole is found in the consensual decision-making practised at the many meetings which I have attended with Ojibwe people over the past two decades. Rather than voting at such meetings, discussion is held until all are 'of one mind.' Ojibwe people I have known rarely act in an authoritarian manner, and consider it rude to tell another person what to do. My own experience is corroborated by Hallowell ${ }^{33}$ who indicates that historically, Ojibwe people suppressed "any impulse to tell someone what to do," saying "In short, no one was in a position to order anyone else around." 34

An authoritarian approach was avoided traditionally, but educational leadership was acknowledged and exercised in a variety of ways. In Ojibwe society individual gifts and talents were recognized, and it was each person's responsibility to share those gifts and talents and to look for the attributes in any of the young which would suggest that they too shared the same gift. It was then the responsibility of those particular adults to nurture and develop that gift to fruition, and to "encourage each individual to use the special gifts they have been given and to do so in a way that benefits everyone, not just themselves." ${ }^{35}$ In this way education transpired hrough mentoring relationships. ${ }^{36}$

Participants' comments suggest that role models and mentors continue to be important for Indigenous education. A traditional cultural practice exercised in the twenty-first century may look somewhat different, but the essential core remains - the importance of relationships with role models as a way of recognizing and achieving potential. For, as Joan said "The whole thing is that kids are good at one thing or another, and to work on that and make them feel that they're part of society, that they are giving to society."

While the extensive literature on mentoring and education ${ }^{37}$ indicates that the importance of mentoring is not exclusive to Indigenous domains, mentoring relationships may be particularly important for Indigenous teaching and learning where learning relationships involve power issues. Indigenous mentors may be particularly important in serving as 'trail blazers' through the 'foreign territory' of a formal education system created by the dominant culture. Like study participants, Haig-Brown and others ${ }^{38}$ have recognized "...the importance of mentorship in helping students learn and apply the rules of the culture of power.... mentorship is needed for students to become insiders in a Discourse..." ${ }^{39}$

Role models may give access to 'power-with' learning relationships rather than 'power-over' learning relationships and thus encourage growth rather than enforce dominance. Leading by example, as students themselves, participants were aware that they were showing their students a path through the foreign territory of formal education. Like some other educators (see Nel Noddings' work, for example, on caring relations in education ${ }^{40}$ ), Indigenous participants were concerned with finding and supporting the development of their students' gifts and with building their students' self-esteem through serving as mentors and role models. Like Indigenous educators Linda Miller Cleary and Thomas Peacock, they were aware that

The relationship between students and teachers is probably more essential than what is taught and how it is taught.... learning cannot begin until the teacher 
is perceived as safe and caring.... But just as caring about students is essential, it is not enough. Students also must learn.... Seeing students on a continuum between where they are at the moment and where they are capable of being or where they want to be is a caring and essential way to think of students. Then the teacher's job is simply to nudge them along the continuum..$^{41}$

Though 'simply nudging' students along may be harder than it sounds, such an approach nonetheless shows a continuing respect for the inherent gifts a student brings to the learning situation and an ongoing continuance of the de-emphasis on authoritarian modes.

\section{The "We" and the "I": Foundational Orientations}

Cultural continuity is apparent in the roles which participants in my study chose to fulfill, roles which demonstrate continuity in women's service to the people and hence to the community. The individual's place in the whole serves to recognize and support the inter-relationships which exist, and to further the whole. This is contrasted with an individualistic orientation which serves to advance the autonomous and distinct over the collective.

Numerous authors have recognized that ways of enacting social orientations are found along a continuum from the individualistic to the collective orientation. For example, Jack Mezirow ${ }^{42}$ uses the terms "organic mode" and "contractual mode" to distinguish between these two fundamental orientations. In the "organic mode" a predominance of organic unities such as family, class or caste, and local community mean that the individual is psychologically assimilated by the values, rules, customs and expectations of the community. Such cultures are contrasted by those favouring the "contractual mode" where social relationships place greater emphasis on the individual rather than the primary group and on contractual rather than organic relationships.

In her article "Ethics: The We and the I", Indigenous author V.F. Cordova speaks of the Indigenous orientation, saying

In the West, codes of conduct are based on the concept of the individual as the "bargaining unit." That is, there is a fundamental description of the human being as essentially an individual which is potentially autonomous. The term autonomous is, in this sense, described as making reference to an individual that exists isolated and solitary. The term implies, also, the notion that this individual can act in such a manner that he becomes a law unto himself: the "I" is conceived as containing the capacity to be "self-determining."

A code of conduct, however, can be based on the description of the human being as a social being; that is, he exists within the confines of the "We".... Between those who would define proper behavior of human beings toward others as based on the We or the I lies a tremendous difference.... Indigenous Americans, just as did the Greeks, found their codes of conduct on the premise 
that humans are naturally social beings. Humans exist in the state of the "We"... The Native American, like the Greeks, relies on the internalization of rules for proper conduct; but unlike the Greeks, the Native American adds to the We definition of human beings the idea of equality. Many outside commentators on Native American lifeways have commented on this notion of equality - that it extends to children; that it promotes an emphasis on consensual decision-making; that it extends even to an individual's actions toward the planet and its many life-forms. ${ }^{43}$

Well-known Indigenous scholar Vine Deloria says this "We mode" is a significant departure from the Western 'mainstream' orientation, stating

Among the most important differences between tribal peoples' and Western thinking is the concentration in the West on the solitary individual to the exclusion of the group - a perspective now rendered obsolete by quantum physics.... In contrast to the West, where "rights" reign supreme, the tribal peoples through family, clan, and societies created a climate in which "responsibility" would be the chief virtue. ${ }^{44}$

(It is interesting to note that Vine Deloria's statement is echoed in another arena entirely, by feminists who have explored women's adult development and interconnectedness, who have also used the terms "rights" and "responsibilities" to outline a framework of independence/interdependence. ${ }^{45}$ An exploration of comparisons is not the intention of this article, but the similarities warrant mention here.)

Cordova's assertions that Indigenous orientations demonstrate a "We mode" are supported by the findings of my study. In my study, participants' comments concerning their motivation, learning and success in the teacher education program yielded much evidence to suggest a "We mode" orientation, including a permeating emphasis on relationships and maintaining strong community connections. For these women, assuming leadership as teachers involved concrete tasks of curriculum development, individual student mentoring, supporting Aboriginal language in the classroom, and other ways of, as Taiaiake Alfred says, "pooling their self-power in the interest of the collective good." ${ }^{46}$

\section{Implications for Indigenous Teacher Education}

If we may accept that the historical "We mode" orientation has persisted and provides a foundational starting point for Indigenous relations, then we must consider the implications of such a finding for Indigenous teacher education programs. How does such an understanding impact upon program design? What program features may be incorporated to recognize the importance of relationships for Indigenous learners; what features to support and allow community connections, family connections, and cultural connections? What staffing considerations should be incorporated in hiring policies? What course content, methods, and learning activities? What benchmarks? 
What implications for the 'nuts and bolts' of teacher education, such as preparing student teachers to deal with classroom management issues, and student evaluation in Indigenous classrooms?

And if we may accept the observations of study participants and others that formal education has not served Indigenous students well; if we may accept the assertions of Indigenous scholars that formal education has furthered a set of epistemic assumptions which continue to marginalize and dominate Indigenous people, ${ }^{47}$ then we must consider even more difficult questions. Who should inform and enact policies and approaches in Indigenous education? Digging deeper still, we must ask who gets to decide what knowledge is legitimate, by what authority? It is important to gain answers to questions such as those posed by Cathryn McConaghy in her excellent book Rethinking Indigenous Education: Culturalism, Colonialism and the Politics of Knowing: "How is it that certain claims to knowledge are able to secure epistemic authority as particular times...? What are the processes by which old knowledge claims are rejected and new gain legitimacy? How do elements of the old persist in the new?" 48

In the face of all these questions, one thing is certain. Finding adequate answers will not be possible without Indigenous educators, politicians and scholars who expect to play central roles and exercise freedom in determining the educational futures of their communities and First Nations.

Some effort has been made to address Indigenous education issues in recent years. While it is beyond the scope of this paper to provide an in-depth exploration here, a few recent developments impacting upon Indigenous teacher education are worth noting. For schools in the provincial school system, the Ontario First Nation, Métis, and Inuit Education Policy Framework published in 2007 by the Ontario Ministry of Education expresses the intention to "increase the capacity of the education system to respond to the learning and cultural needs of First Nation, Métis and Inuit students." ${ }^{49}$ Strategies aimed at improving Indigenous education student achievement are addressed at the Ministry, school board, and school level, and include hiring more Indigenous educators, supporting training in Indigenous cultural content and teaching methods, and a variety of ways of raising awareness of and responding to Indigenous learning needs. ${ }^{50}$ Further to this policy, supplemental funds are being released to Ontario school boards to launch the implementation of the Framework, and to offer Native Language and Native Studies courses as well as support programs that assist Indigenous students. ${ }^{51}$

For First Nation schools, community control has allowed somewhat greater freedom of choice over school curriculum content and development, educational practice, and Indigenous language instruction. However, these communities and schools still suffer from serious under-funding due to Federal government shortfalls, while provincial and national Indigenous organizations strive for equitable treatment. ${ }^{52}$

At the national level, a Summit on First Nations, Métis and Inuit Education will be held in 2009 with leaders in Indigenous education, as part of the Council of Ministers of Education (CMEC) National Aboriginal Education Action Plan. The summit will offer the opportunity to discuss strategies to 'eliminate the gap between the educational achievement of Canada's First Nations, Métis and Inuit students and non-Indigenous students.' 
Other capacity-building initiatives are underway to further Canadian awareness of and opportunities to learn from Indigenous educators. One auspicious example is the Aboriginal Learning Knowledge Centre, established in 2006 by the Canadian Council on Learning. Indigenous scholarship is acknowledged and supported through the Centre and elsewhere, as Indigenous scholars continue the work which study participants have engaged in; exploring Indigenous knowledge and educational principles, and articulating Indigenous education frameworks arising from Indigenous language and thought. This is vital work to move away from colonizing influences in education, and toward more authentic Indigenous perspectives.

Though old frameworks persist, and most of the effort for positive change involves working within/pushing against these frameworks, it is refreshing to contemplate a brighter future, and to focus on positive possibilities, for, as Navajo writer Robert Yazzie points out, much of current "Indian thinking is basically a response to the ongoing pattern of the colonization of Indigenous peoples." ${ }^{53}$ His comment resonates and implies that with this awareness and with increased opportunities for Indigenous people to make the decisions on matters affecting them, it may be possible to move beyond intellectual positions couched in reaction/resistance to new outlooks characterized by proactive agency. Linda Tuhiwai Smith says that it is time to ask "What is it we can celebrate? What is it we need to think more carefully about? What is it we can abandon? And, what is it that we need to keep building?" 54 She says

In my view there has been a momentum of change in our communities. I have witnessed this through my travels and studied it through the texts of indigenous writers. It is obvious particularly in countries of the First World in which indigenous communities have a particular place as colonised minorities.... The change I have seen has mostly been a change of mindset.... what I have seen that is worth celebrating is a sense of purpose and an acknowledgement that we have got to do things better, together, and that the way forward is to take our culture with us, not abandon it. The way forward is to keep our identity, not discard it. The way forward is to celebrate who we are, not be ashamed of it. Those are simple changes at one level, but they are hugely transformative in terms of throwing off the shackles of colonisation. That momentum of change in mindset is reflected in the many indigenous communities I have visited across the world..$^{55}$

\section{Conclusion}

In conclusion, it is hoped that this paper may offer a small contribution toward a growing understanding of Indigenous students' and in particular, Indigenous women's concerns in teacher education. Out of such understanding must come further discussion and action aimed at increasing the efficacy of policies and programs to support Indigenous goals as learners and teachers, who intend to continue "to remain working for the People." 


\section{Notes}

1. Kathryn M. Freeman, "Ojibwe Women as Adult Learners in a Teacher Education Program: Towards an Understanding of Aboriginal Women's Experiences of Learning and Change" (doctoral thesis, University of Toronto, 2001).

2. D.A. Mihesuah, ed., Natives and Academics: Researching and Writing about American Indians (Lincoln, Nebraska: University of Nebraska Press, 1998); Linda Tuhiwai Smith, Decolonizing Methodologies: Research and Indigenous Peoples (London: Zed Books, 1999).

3. See, for example, Taiaiake Alfred. Peace, Power and Righteousness: An Indigenous Manifesto (Don Mills: Oxford University Press, 2nd edition, 2008); D.A. Mihesuah and A. Cavender Wilson, eds., Indigenizing the Academy: Transforming Scholarship and Empowering Communities (Lincoln, Nebraska: University of Nebraska Press, 2004): 5-25; K. G. Swisher, "Why Indian People Should be the Ones to write about Indian Education," in D.A. Mihesuah, ed., Natives and Academics: Researching and Writing About American Indians (Lincoln, Nebraska: University of Nebraska Press, 1998), 190-99; Kim Anderson, Recognition of Being: Reconstructing Native Womanhood (Toronto: Second Story Press, 2000).

4. Statistics Canada. Educational Portrait of Canada, 2006 Census: Aboriginal Population, http://www12.statcan.ca/ english/census06/analysis/education/proportion.cfm (accessed August 15, 2008).

5. Ibid.

6. Statistics Canada. Census of Population 2006, http://www12.statcan.ca/english/ census06/analysis/education/ tables/table2.htm\#top (accessed August 15, 2008).

7. Statistics Canada. 2008. Ontario (table). Aboriginal Population Profile. 2006 Census. Statistics Canada Catalogue no. 92-594-XWE. Ottawa. Released January 15, 2008, http:// www12.statcan.ca/english/ census06/data/profiles/aboriginal/Index.cfm?Lang=E (accessed September 10, 2008).

8. Jerome Bruner, Actual Minds, Possible Worlds (Cambridge: Harvard University Press, 1986); N. Lyons, "Dilemmas of Knowing: Ethical and Epistemological Dimensions of Teachers' Work and Development," Harvard Educational Review 60, no. 2 (Cambridge: Harvard University Press, 1990), 159-180; Nel Noddings, "Caring and Competence," in G. Griffen, ed., The Education of Teachers (Chicago: National Society of Education, 1999), 205-20.

9. T. Barer-Stein, "Culture in the Classroom," in T. Barer-Stein \& J. Draper, eds., The Craft of Teaching Adults (Toronto: Culture Concepts, 1988), 145-64.

10. The term 'Stockholm Syndrome' refers to a psychological response sometimes seen in an abducted hostage, in which the hostage shows signs of loyalty to the hostage-taker, regardless of the danger (or at least risk) in which they have been placed. The syndrome is named after the Norrmalmstorg robbery of Kreditbanken at Norrmalmstorg, Stockholm, Sweden, in which the bank robbers held bank employees hostage from August 23 to August 28 in 1973 . In this case, the victims became emotionally attached to their victimizers, and even defended their captors after they were freed from their six-day ordeal. http:// en.wikipedia.org/wiki/Stockholm_syndrome (accessed October 18, 2008).

11. The 'seven gifts' or 'seven grandfathers' teachings are traditional teachings, several of which pertain to 'right relations' with other. These gifts are teachings concerning honesty, humility, courage, wisdom, respect, generosity and love. See Eddie Benton Banai, The Mishomis Book: The Voice of the Ojibwe (St. Paul: Indian Country Press \& Publications, 1979).

12. E.J. Danziger, The Chippewas of Lake Superior (Oklahoma: University of Oklahoma Press, 1990), 14. 
13. N. Shoemaker, in N. Shoemaker, ed., Negotiators of Change: Historical Perspectives on Native American Women. (London: Routledge, 1995), 2.

14. Royal Commission on Aboriginal Peoples (RCAP). Volume 3. Gathering Strength: Report of the Royal Commission on Aboriginal Peoples (Ottawa: Minister of Supply and Services Canada, 1996), 433.

15. Kim Anderson, Recognition of Being: Reconstructing Native Womanhood (Toronto: Second Story Press, 2000).

16. Ibid., 169.

17. See, for example, Heather Howard-Bobiwash and Susan Krouse, "Keeping the Campfires Going: Urban American Indian Women's Community Work and Activism," in The American Indian Quarterly (June, 2003).

18. Jeannette Armstrong, "Words," in Telling it: Women and Language Across Cultures (Vancouver: Press Gang Publishing, 1990), 25.

19. The Royal Commission on Aboriginal Peoples study, involving round table consultations with Aboriginal organization and community representatives across Canada, was a five-year effort resulting in the publication of a final report in November, 2006. The report (five volumes, 4,000 pages) presented 440 recommendations and called for broad and significant changes to the relationship between Indigenous and non-Indigenous people and governments in Canada. Many recommendations pertaining to education have yet to be acted upon.

20. RCAP, Vol. 3, 434, 468.

21. Marie Battiste, "Maintaining Aboriginal Identity, Language and Culture in Modern Society," in Marie Battiste, ed., Reclaiming Indigenous Voice and Vision (Vancouver: UBC Press, 2000); 198.

22. Celia Haig-Brown, Taking Control: Power and Contradiction in First Nations Adult Education (Vancouver: U.B.C. Press, 1995), 229.

23. Jeannette Armstrong, cited in C. Miller and P. Chuchryk, eds., Women of the First Nations (Winnipeg: University of Manitoba Press, 1997), xi.

24. RCAP, Vol. 3, 433.

25. Diane Hill, Holistic Learning: A Model of Education Based on Aboriginal Cultural Philosophy (Unpublished Master's thesis, St. Francis Xavier University, Antigonish, Nova Scotia, 1999): 31.

26. J. Cruikshank, in J. Cruikshank, A. Sidney, K. Smith, and A. Nedd, Life Lived Like a Story (Lincoln: University of Nebraska Press.1990), 3.

27. See, for example, early Jesuit records cited by Christopher Vecsey in his book Traditional Ojibwa Religion and its Historical Changes. These references illuminate the primacy and pervasive nature of Ojibwe relations of equality, fitting into, rather than having dominion over a universal order where all animate beings - humans, plants, animals, and natural entities including rocks and trees were believed to possess personal souls. Natural entities were viewed not as foreign objects, but as kin to humans. Historical accounts indicate that in the past the Ojibwe person believed that "all objects have life, and life is synonymous with power..." and that it was important to "treat everything he sees or touches with respect befitting a thing that has a soul and shadow not unlike his own." C. Vecsey, Traditional Ojibwa Religion and its Historical Changes (Philadelphia. The American Philosophical Society, 1983), 62. See also Diamond Jenness, "The Ojibwa Indians of Parry Island. Their Social and Religious Life," Bulletin 78. Anthropological Series 17 (Ottawa: Canada Department of Mines and Resources, 1935): 21. 
28. J. Dumont, in Hill, Holistic Learning, 116.

29. Comments excerpted from lecture notes; address given at the Ontario Institute for the Study of Education by Dr. Cecil King, winter 1992.

30. Marie Battiste, Ibid, Richard Powless, "The New Agenda: Building Upon the History of First Nations Education in Ontario", 2004, www.chiefsofontario.org/education/ manifesto/a\%20history\%20of\%20first $\% 20$ nations $\% 20$ education.doc, (accessed October 17, 2008); 3.

31. Linda Tuhiwai Smith, "Activism, Leadership and the New Challenges for Indigenous Communities," Dr. Charles Perkins A.O. Annual Memorial Oration 2004. Address delivered at the University of Sydney, October 26, 2004, www.koori.usyd.edu.au/news/2004_smith_ address.pdf (accessed October 17, 2008); 3.

32. Verna Patronella Johnston, quoted in R.M. Vanderburgh, I am Nokomis too. The Biography of Verna Patronella Johnson (Don Mills, Ontario: General Publishing Co. Ltd., 1977), 182.

33. Irving Hallowell, Culture and Experience (Philadelphia: University of Pennsylvania Press, 1955).

34. Ibid, 135.

35. RCAP, Vol, 3, 491.

36. For references to mentoring as a traditional educational practice among Indigenous peoples, see, for example, Danziger, The Chippewas of Lake Superior; RCAP, Vol. 3, Chapter Five; A. Shenandoah, "Everything has to be in Balance," in José Barreiro, ed., Indian Roots of American Democracy (Ithaca, New York: Akwehon Press, Cornell University, 1992).

37. For references on women and mentors, a useful resource is the annotated bibliography (online pages last modified in March 2008) found at http://womenst.library. wisc.edu/bibliogs/mentor.html.

38. Haig-Brown, Taking Control, 228-29.

39. Ibid, 228.

40. Nel Noddings, "Caring in Education," the encyclopedia of informal education, 2005, www.infed.org/biblio/ noddings_caring_in_education.htm (accessed March, 2008).

41. Linda Miller Cleary, Thomas D. Peacock, Collected Wisdom: American Indian Education (Needham Heights, Massachusetts, 1998), 245.

42. Jack Mezirow, "Perspective Transformation," in Adult Education, XXVIII, no. 2 (1978): 100-110.

43. V.F. Cordova, "The We and the I," in Anne Waters, ed., American Indian Thought (Oxford: Blackwell Publishing, 2004): 175-76.

44. Vine Deloria Jr., "Philosophy and the Tribal Peoples," Ibid, 10.

45. See, for example, these terms used in the work of Carol Gilligan, In a Different Voice (Boston: Harvard University Press, 1982).

46. Taiaiake Alfred, Peace, Power and Righteousness. An Indigenous Manifesto (Don Mills: Oxford University Press, 2008), 25.

47. Linda Tuhiwai Smith, Decolonizing Methdologies: Research and Indigenous Peoples (New York: Palgrave, 1999), 58-77; Marie Battiste, Ibid; 196-99; Cathryn McConaghy, "Scientific Culturalism: Institutionising Colonial Value," in Rethinking Indigenous Education: Culturalism, Colonialism and the Politics of Knowing (Flaxton, Qld: Post Pressed, 2000); 126; see also Devon Abbott Mihesuah and Angela Cavender Wilson, eds., Indigenizing the 
Academy: Transforming Scholarship and Empowering Communities (Nebraska: University of Nebraska Press, 2004).

48. Cathryn McConaghy, Rethinking Indigenous Education: Culturalism, Colonialism and the Politics of Knowing (Flaxton, Qld: Post Pressed, 2000), 1.

49. Ministry of Education, Aboriginal Education Office. Ontario First Nation, Métis, and Inuit Education Policy Framework (Ottawa: Queen's Printer for Ontario, 2007): 7. Also available at http://www.edu.gov.on.ca.

50. Ibid. A detailed discussion on these strategies is provided on pages 11 to 20 , and available online at http://www.edu.gov.on.ca.

51. In 2007, $\$ 12.5$ million was invested to support the implementation of the First Nation, Métis and Inuit Education Policy Framework. An additional \$10.5 million has been introduced in 2007-08 to provide increased funding for school boards to offer Native Language and Native Studies courses, and support programs. http://ogov.newswire.ca/ontario/ GPOE/2007/04/05/c2815.html?!match=\&lang=_e.html (accessed June, 2008).

52. Ontario Native Education Counselling Association Education Fact Sheet, www. oneca.com/news_temp/education_campaign/fact_sheet.pdf (accessed October 18, 2008).

53. Robert Yazzie, "Indigenous Peoples and Postcolonial Colonialism," in Reclaiming Indigenous Voice: 43.

54. Linda Tuhiwai Smith, Dr. Charles Perkins A.O. Annual Memorial Oration 2004; 2.

55. Linda Tuhiwai Smith, Ibid; $2-3$. 